\title{
ANALISA DAN PENERAPAN E-COMMERCE PADA SPORT KUY STORE DENGAN PENDEKATAN BUSINESS MODEL CANVAS
}

\author{
Hendry Nugroho ${ }^{1)}$, Dian Anubhakti ${ }^{2)}$ \\ ${ }^{1}$ Sistem Informasi, Fakultas Teknologi Informasi, Universitas Budi Luhur \\ ${ }^{1,2}$ Jl. Raya Ciledug, Petukangan Utara, Kebayoran Lama, Jakarta Selatan 12260 \\ E-mail : hendryrpl@gmail.com ${ }^{1)}$, dian.anubhakti@budiluhur.ac.id ${ }^{2)}$
}

\begin{abstract}
Abstrak
Pada umumnya proses jual beli dilakukan secara langsung atau tatap muka antara penjual dan pembeli. Artinya kegiatan jual beli hanya bisa dilakukan dalam geografis tertentu dan waktu yang terbatas. Pada penelitian ini penulis merancang dan mengembangkan sistem E-Commerce dengan membangun toko online dan melakukan pemasaran melalui media sosial dengan studi kasus di Sport Kuy Store menggunakan pendekatan Business Model Canvas. BMC digunakan untuk menggambarkan model bisnis yang akan dipakai pada waktu yang akan datang bagi Sport Kuy Store. Penelitian ini berfokus pada memberikan kemudahan bagi pengguna, memberikan antar muka yang menarik, penyampaian informasi barang yang dijual, dan strategi pemasaran pada media sosial agar para pelanggan dapat dengan mudah mendapatkan informasi mengenai produk yang terdapat pada Sport Kuy Store. Dengan adanya website E-Commerce dan pemasaran beserta strateginya di media sosial, diharapkan dapat meningkatkan pendapatan Sport Kuy Store serta memperkenalkan produknya ke ruang lingkup yang lebih luas sehingga dapat menjawab persoalan penjualan secara langsung.
\end{abstract}

Kata kunci: E-Commerce, Toko Online, Penjualan, Business Model Canvas

\section{PENDAHULUAN}

Perkembangan teknologi dan informasi terjadi sangat cepat. Hal ini dapat dirasakan dari hadirnya berbagai macam tren teknologi baru yang bertujuan untuk mempermudah, mempercepat, memastikan validitas data yang diperoleh. Di era sekarang, jika ingin mendapatkan keuntungan maksimal dari proses jual beli, maka penjual harus memperluas ruang lingkup penjualannya, sementara yang terjadi pada proses jual beli konvensional adalah ruang lingkup penjualannya sangat terbatas. Dengan itu muncul teknologi baru yang bernama E-Commerce, E-Commerce merupakan improvisasi dari proses jual beli. Dengan adanya e-commerce diharapkan penjual dapat memperluas ruang lingkup penjualannya.

Pada Sport Kuy Store, produk yang dijual adalah jersey sepak bola. Masalah yang ditemukan adalah proses jual beli yang terhambat dan informasi yang diperoleh tidak akurat dikarenakan proses jual beli masih menggunakan cara konvensional. Mengakibatkan kurang maksimalnya hasil yang didapat dari penjualan.

Masalah pada Sport Kuy Store dapat diatasi dengan memanfaatkan sistem informasi penjualan yang dikolaborasikan dengan e-commerce sebagai media penjualan dan pemasaran. Dengan keakuratan struktur data yang dirancang dan strategi penjualan yang baik yang dibangun melalui pendekatan business model canvas diharapkan dapat mengatasi masalah yang ada dan dapat bermanfaat bagi Sport Kuy Store.

E-commerce adalah suatu aktivitas bisnis yang melibatkan pembeli, penjual, manufaktur, dan service provider yang dihubungkan melalui jaringanjaringan komputer yaitu internet [1].

Dapat disimpulkan bahwa e-commerce adalah improvisasi modern dari transaksi jual beli, yang mana pada transaksi konvensional, aktivitas bisnis dilakukan pada ruang lingkup yang terbatas dimana para pelaku bisnis berada. Sementara pada $e$ commerce, aktivitas bisnis dapat dilakukan dimana saja dengan menggunakan bantuan jaringan komputer yaitu internet.

Sistem dapat diartikan sebagai kumpulan komponen dan variabel yang saling berhubungan, berinteraksi, terorganisasi, dan bergantung satu sama lain [2].

Informasi adalah data yang telah dikelola dan diproses sehingga dapat memberikan arti yang mudah dipahami dan memperbaiki proses pengambilan keputusan [3].

Business Model Canvas adalah suatu framework yang yang digunakan untuk menggambarkan, memvisualisasikan, menilai, dan mengubah model bisnis [4].

UML adalah sebuah bahasa yang dijadikan standar dalam industri untuk visualisasi, merancang, dan mendokumentasikan sebuah software [5].

SEO adalah serangkaian proses yang dilakukan secara sistematis untuk meningkatkan volume dan kualitas trafik ke dalam sebuah website dengan tujuan meningkatkan ranking website di dalam mesin pencari [6]. 


\section{METODE PENELITIAN}

\subsection{Teknik Pengumpulan Data}

Teknik pengumpulan data yang dilakukan adalah menggunakan cara:

a. Wawancara

Dalam wawancara ini peneliti melakukan wawancara semi terstruktur dimana peneliti hanya menyiapkan beberapa pertanyaan yang dibutuhkan untuk mendapatkan informasi. Pertanyaan itu sendiri ditanyakan kepada pemilik toko dan bagian penjualan pada toko tersebut.

b. Observasi

Penulis mengamati langsung mengenai proses jual beli yang terjadi pada Sport Kuy Store untuk mendapatkan data yang dibutuhkan.

c. Teknik Dokumentasi

Pada tahap ini penulis mengumpulkan dokumen maupun arsip yang terdapat pada Sport Kuy Store yang terkait dengan proses bisnis di sana.

d. Literatur

Melakukan pencarian data, informasi yang berhubungan dengan kasus penelitian melalui internet, buku-buku ilmiah, serta karangan ilmiah dari peneliti sebelumnya.

\subsection{Metodologi Analisis}

Saat merancang sistem e-commerce, penulis menganalisa data yang sedang berjalan untuk mendapatkan solusi dari masalah yang terjadi. Untuk mempermudah proses penelitian dalam menganalisa masalah, penulis melakukan beberapa tahapan diantaranya:

a. Activity Diagram

Menggambarkan alur kerja ataupun alur bisnis dan urutan aktivitas bisnis yang terjadi pada Sport Kuy Store.

b. Use Case Diagram

Menjelaskan fungsi-fungsi sistem melalui penggambaran jika dilihat dari sudut user atau orang yang berada di luar sistem.

\subsection{Metodologi Perancangan Sistem}

Dalam menyusun model rancangan pada penelitian ini, penulis menggunakan tools perancangan dengan tahapan sebagai berikut:

a. Business Model Canvas

BMC digunakan untuk menggambarkan future business model yang akan diterapkan pada Sport Kuy Store. BMC juga yang akan mendasari segala strategi bisnis yang akan diterapkan.

b. Class Diagram

Class Diagram digunakan untuk menggambarkan struktur antar kelas yang terdapat pada sistem serta hubungan-hubungannya dan memberikan detail pada tiap kelas tersebut.

c. Interaction Flow Modeling Language

\begin{abstract}
Interaction Flow Modeling Language digunakan untuk merancang konten, menggambarkan interaksi pengguna dengan sistem, serta mengatur perilaku dari front-end aplikasi pada kasus ini adalah web e-commerce Sport Kuy Store.
\end{abstract}

\section{HASIL DAN PEMBAHASAN}

\subsection{Business Model Canvas}

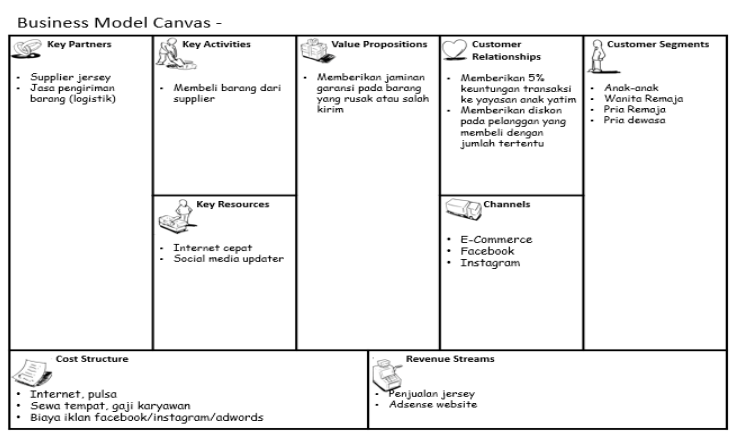

Gambar 1. Business Model Canvas Sport Kuy Store

Berikut akan dijelaskan mengenai deskripsi dari elemen-elemen business model canvas pada Sport Kuy Store.

a. Customer Segments

Target pasar utama dari Sport Kuy Store adalah anak-anak, wanita remaja, pria remaja, dan pria dewasa.

b. Value Propositions

Pada Sport Kuy Store yang menjadi value propositions adalah pemberian garansi pada barang yang rusak atau salah kirim.

c. Customer Relationships

Sport Kuy Store menjaga pelanggan dengan cara memberikan diskon pada pelanggan dengan pembelian jumlah tertentu, serta keuntungan akan diberikan kepada yayasan anak yatim.

d. Revenue Streams

Sport Kuy Store mendapat keuntungan dari penjualan jersey serta adsense website yang ditargetkan menjadi keuntungan jangka panjang.

e. Key Resources

Sport Kuy Store membutuhkan internet cepat dan social media updater untuk melakukan update konten pada website e-commerce maupun pada media sosial lainnya.

f. Key Activities

Sport Kuy Store tidak memproduksi barang sendiri melainkan membeli barang dari supplier. Aktivitas lainnya adalah melakukan update konten pada media sosial dan website serta melayani pertanyaan dan keluhan pelanggan, melakukan pemasaran, dan packing barang.

g. Key Partners 
Sport Kuy Store bekerja sama dengan pihak supplier jersey, logistik pihak ketiga dan admin website.

h. Cost Structure

Biaya yang dikeluarkan Sport Kuy Store yaitu biaya sewa toko, gaji karyawan, internet dan pulsa, dan biaya iklan pada media sosial.

\subsection{Proses Bisnis Sistem Usulan}

a. Proses Pendaftaran Pelanggan

Proses pendaftaran pelanggan dilakukan melalui web e-commerce. Pengguna perlu memasukkan email dan password pada form pendaftaran. Sistem akan memeriksa apakah email yang didaftarkan sudah pernah terdaftar sebelumnya. Jika sudah pernah terdaftar maka sistem akan memberi peringatan untuk mengganti email. Jika belum sistem akan menyimpan data baru ke database.

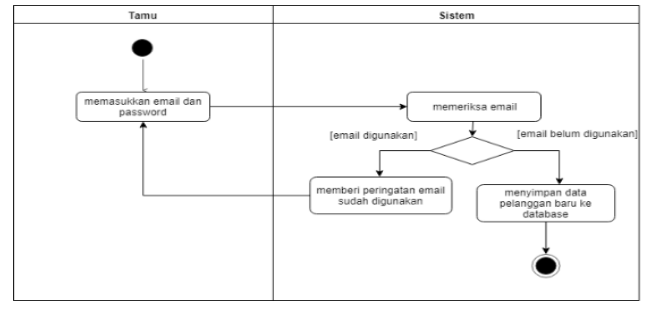

Gambar 2. Activity diagram pendaftaran pelanggan

b. Proses Pengelolaan Keranjang Belanja

Proses pengelolaan keranjang belanja dilakukan melalui web e-commerce. Jika pelanggan ingin membeli produk, maka pelanggan bisa memilih produk lalu memasukkannya ke dalam keranjang belanja lalu sistem akan menampilkan daftar keranjang belanja. Jika pelanggan ingin mengubah item belanja, sistem akan memberi respon dengan perubahan jumlah item. Jika pelanggan ingin menghapus item, sistem akan memberi respon dengan menghapus item dari keranjang belanja.

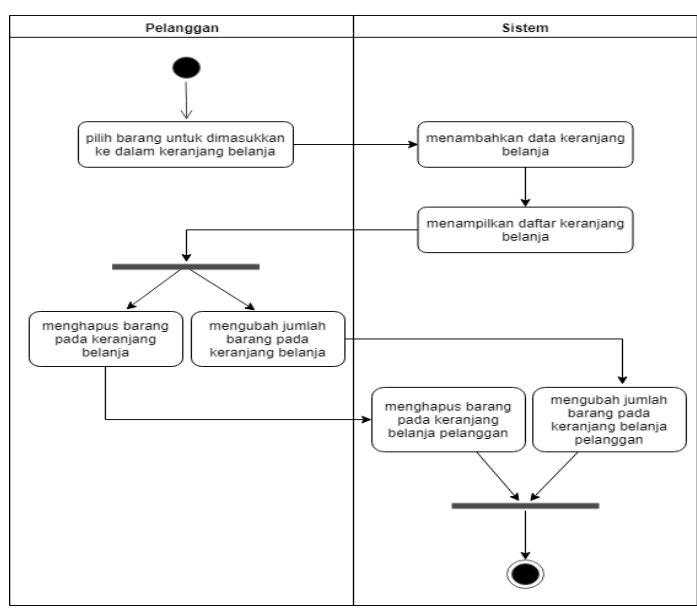

Gambar 3. Activity diagram pengelolaan keranjang belanja c. Proses Penyelesaian Pesanan

Setelah selesai memasukkan barang yang ingin dibeli ke dalam keranjang belanja, pelanggan akan menyelesaikan pesanan dengan melengkapi data alamat pengiriman lalu sistem akan merespon dengan menampilkan ongkos kirim dan total yang harus dibayar. Setelah itu pelanggan dapat melakukan order dengan menekan tombol place order kemudian sistem akan menyimpan data pemesanan ke dalam dabatase.

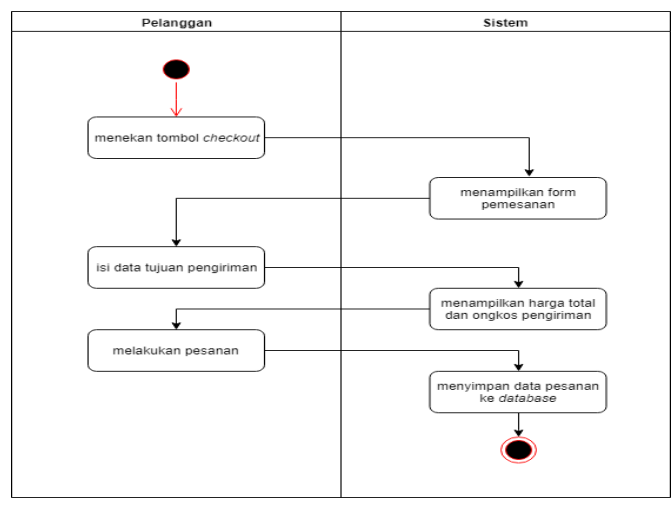

Gambar 4. Activity diagram proses penyelesaian pesanan

\section{d. Proses Pembayaran}

Setelah pelanggan melakukan pesanan, sistem akan memberitahukan nomor rekening penjual, lalu pelanggan dapat melakukan pembayaran melalui transfer bank. Setelah transfer, pelanggan harus mengunggah bukti pembayaran ke web e-commerce.

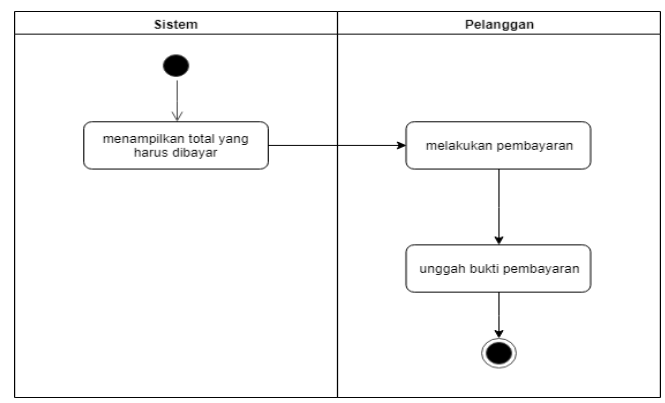

Gambar 5. Activity diagram proses pembayaran

\section{e. Proses Pengiriman}

Setelah pelanggan melakukan pembayaran dan mengunggah bukti pembayaran, pemilik toko selaku admin melakukan pengecekan terhadap bukti bayar pelanggan. Jika bukti pembayaran tidak valid, pesanan akan ditolak. Jika bukti pembayaran valid, admin akan melakukan konfirmasi pembayaran dan melanjutkan ke proses pengiriman barang. Barang akan dikirim melalui jasa logistik pihak ketiga. Setelah admin menerima resi dari pihak logistik, admin akan melakukan input resi ke dalam sistem. Setelah itu sistem akan memberi tahu pembeli bahwa barang telah dikirim menggunakan jasa 
ekspedisi dengan cara mengirimkan detil pembelian dan resi kepada pembeli.

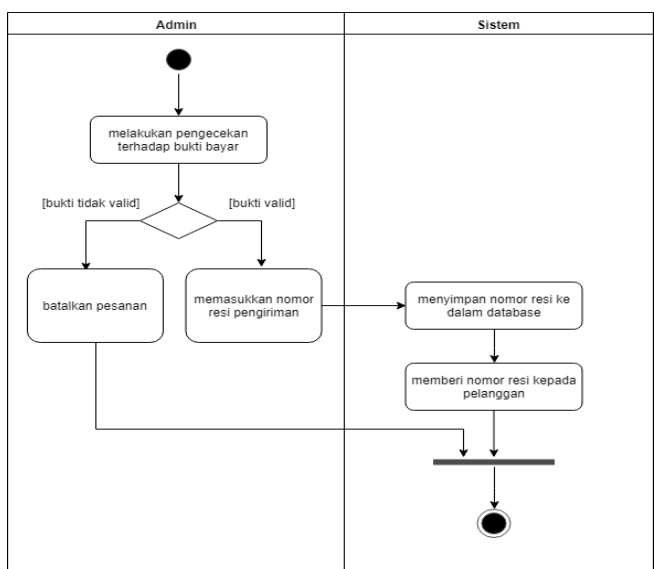

Gambar 6. Activity diagram proses pengiriman

\section{f. Proses Pengembalian Barang}

Setelah pelanggan menerima barang dari penjual, pelanggan memeriksa barang. Jika barang yang dikirim sesuai dengan keinginan, pelanggan bisa menyelesaikan pesanan melalui web ecommerce. Jika tidak, pelanggan bisa mengajukan pengembalian barang dengan meng-upload bukti barang yang ingin dikembalikan beserta alasannya. Admin akan memeriksa apakah bukti yang dikirim pelanggan valid, jika valid admin akan melakukan konfirmasi pengembalian barang, jika tidak admin akan menolak pengajuan dan menyelesaikan pesanan.

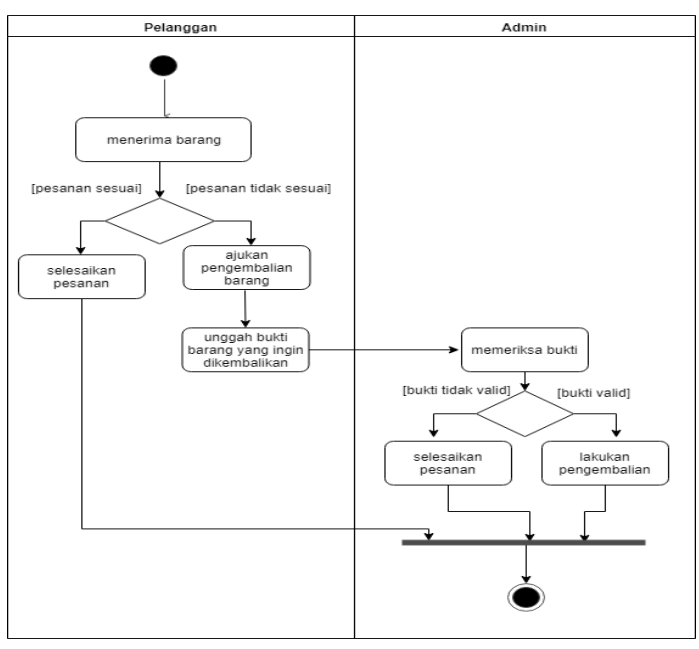

Gambar 7. Activity diagram proses pengembalian

3.3. Use Case

a. Master

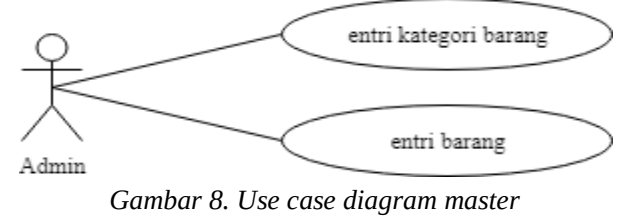

b. Transaksi pemesanan

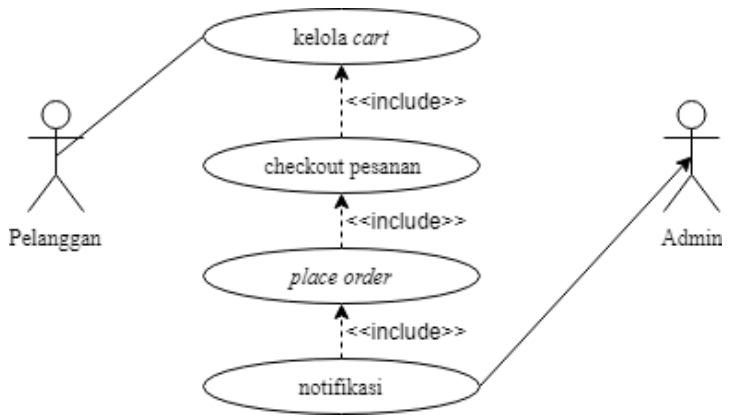

Gambar 9. Use case diagram transaksi pemesanan

c. Transaksi pembayaran dan pengiriman

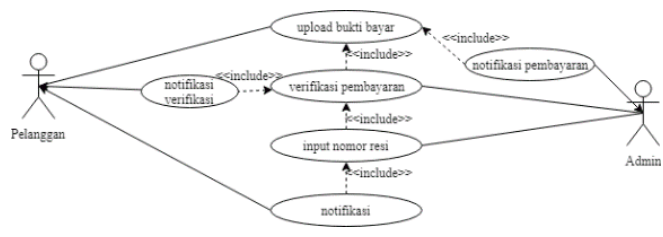

Gambar 10. Use case diagram transaksi pembayaran dan pengiriman

d. Transaksi pengembalian

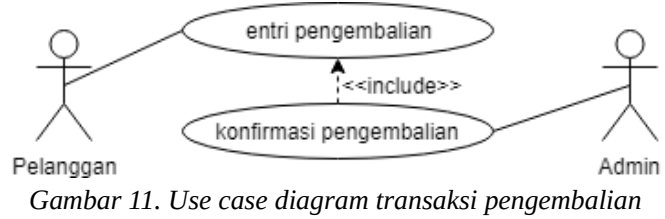

e. Laporan

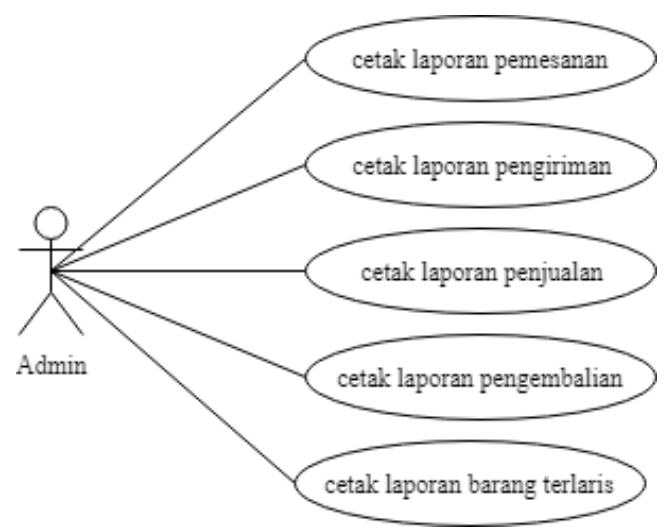

Gambar 12. Use case diagram laporan

\subsection{Model Data}

a. Class Diagram 


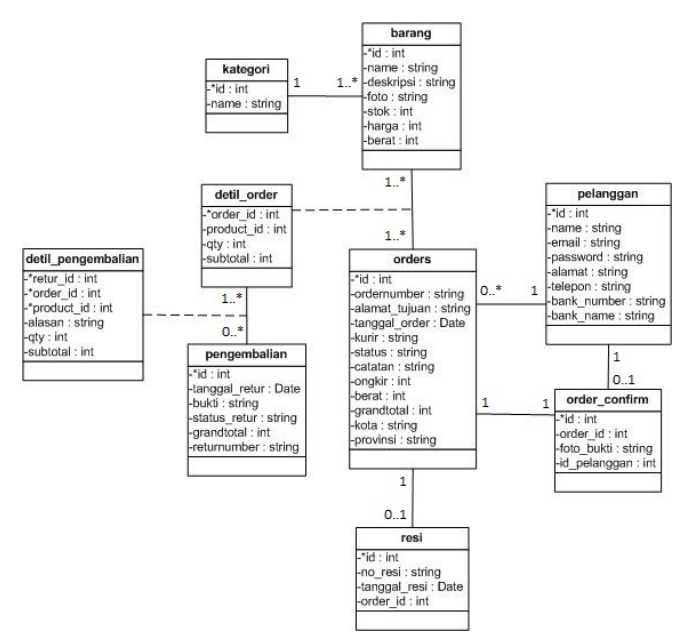

Gambar 13. Class diagram sport kuy store

b. Interaction Flow Modeling Language

Berikut diagram IFML dari core aplikasi web e-commerce yaitu pada transaksi pemesanan:

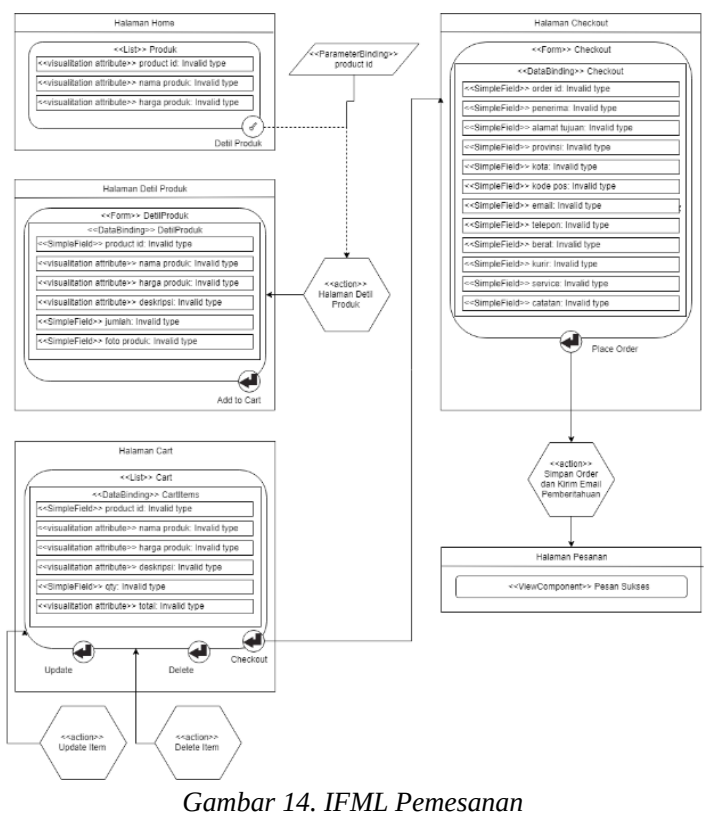

3.5. Rancangan Layar

a. Rancangan Layar Halaman Register

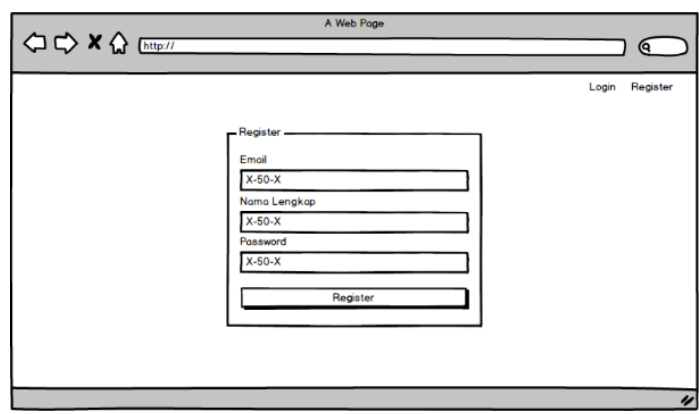

Gambar 15. Rancangan layar halaman register b. Rancangan Layar Keranjang Belanja

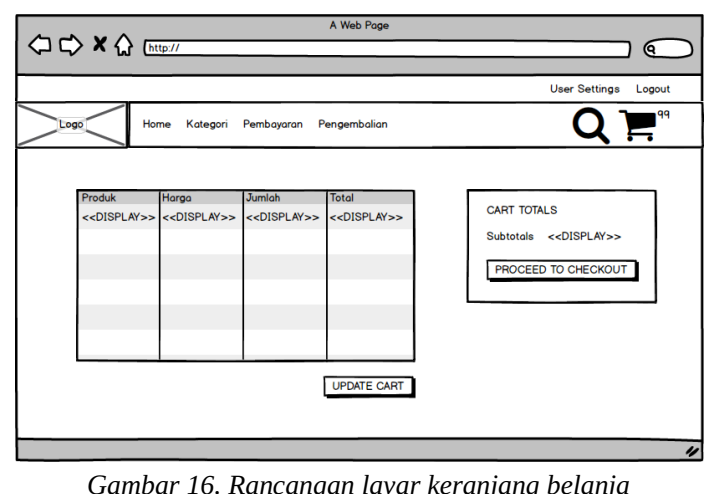

c. Rancangan Layar Halaman Checkout

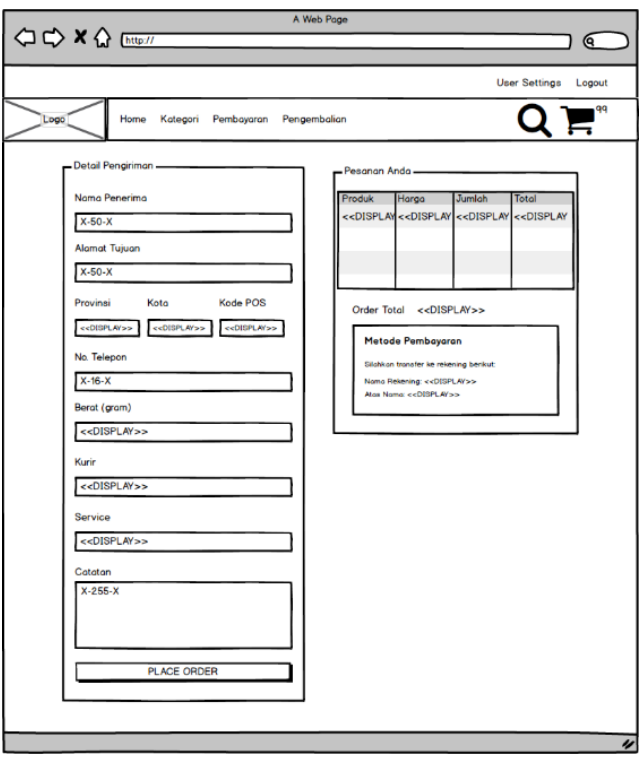

Gambar 17. Rancangan layar halaman checkout

d. Rancangan Layar Detil Pesanan

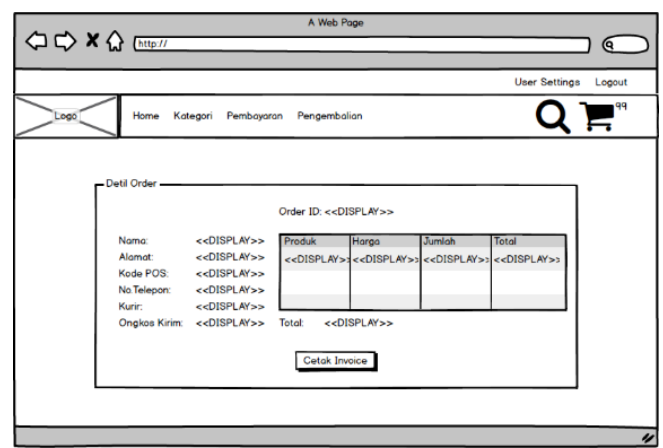

Gambar 18. Rancangan layar detil pesanan

e. Rancangan Layar Detil Pengembalian 


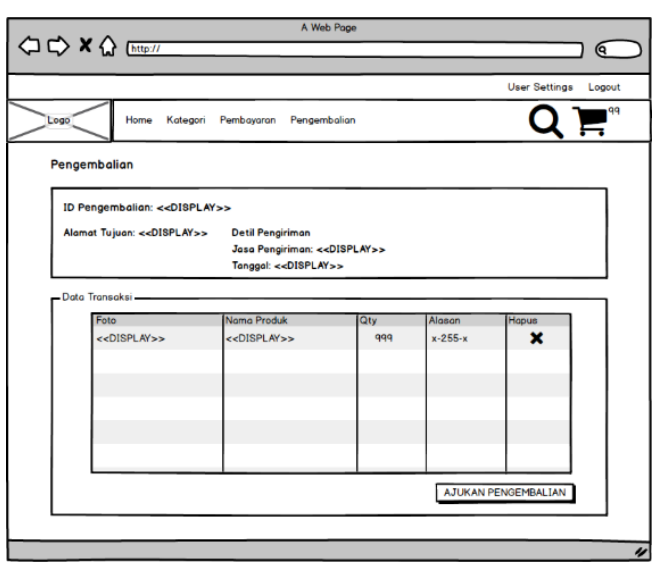

Gambar 19. Rancangan layar detil pengembalian

f. Rancangan Layar Cetak Laporan

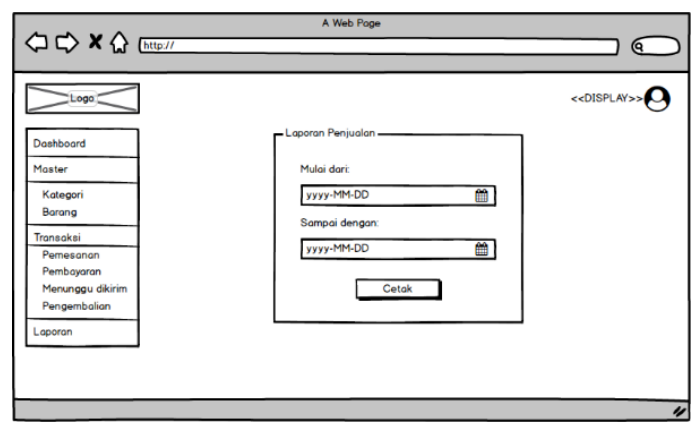

Gambar 20. Rancangan layar cetak laporan

\section{KESIMPULAN}

Dari proses analisis, perancangan, implementasi sistem hingga strategi pemasaran, kesimpulan yang bisa diambil adalah:

a. Dengan adanya katalog produk di web, pelanggan maupun admin dapat mengetahui informasi mengenai barang yang terdapat di Sport Kuy Store.

b. Dengan adanya keranjang belanja, pengguna website bisa menyimpan lebih dari satu barang untuk dibeli.

c. Dengan adanya modul pemesanan, admin bisa lebih mudah mengetahui data pesanan pelanggan beserta detilnya.

d. Dengan adanya modul pengembalian, admin bisa lebih mudah mengetahui data pengembalian barang.

e. Dengan adanya modul laporan, admin bisa lebih mudah mendapatkan data laporan yang lebih terstruktur dan akurat.

\section{DAFTAR PUSTAKA}

[1] JAUHARI, Jaidan, "Upaya pengembangan usaha kecil dan menengah (UKM) dengan memanfaatkan e-commerce.” Jurnal Sistem Informasi, 2014, 2.1, pp. 159-161.

[2] HUTAHAEAN, Jeperson. Konsep sistem informasi. Deepublish, 2015.

[3] ROMNEY, M. B.; STEINBART, P. J, “Sistem Informasi Akuntansi (Accounting Information Systems)” Terjemahan Kikin S. Nur S. dan Novita P, 2016. Jakarta:Salemba Empat.

[4] Osterwalder, Alexander \& Pigneur, Yves., Business Model Generation. Jakarta: PT Elex Media Komputindo, 2012

[5] Sugiarti, Y. Analisis \& Perancangan UML (Unified Modeling Language) Generated VB. 6. Yogyakarta: Graha Ilmu. 2013

[6] Hernawati, Kuswari., 16 Januari 2013, Optimalisasi SEO (SearchEngine Optimizer) sebagai upaya meningkatkan unsur Visibility dalam Webometric, http://staff.uny.ac.id/sites/default/files/seo \%20webometric.pdf 